\title{
Bax deficiency extends the survival of Ku70 knockout mice that develop lung and heart diseases
}

\author{
$\mathrm{J} \mathrm{Ngo}^{1,2}$, M Matsuyama ${ }^{1}$, C Kim ${ }^{1}$, I Poventud-Fuentes ${ }^{1}$, A Bates ${ }^{1}$, SL Siedlak ${ }^{3}$, H-g Lee ${ }^{3}$, YQ Doughman ${ }^{4}$, M Watanabe ${ }^{2,4}$, A Liner $^{1}$, \\ B Hoit ${ }^{1}$, N Voelkel ${ }^{5}$, S Gerson ${ }^{1,6}$, P Hasty ${ }^{7}$ and S Matsuyama ${ }^{*, 1,6}$
}

Ku70 (Lupus $\mathrm{Ku}$ autoantigen p70) is essential in nonhomologous end joining DNA double-strand break repair, and $k u 70^{-/-}$mice age prematurely because of increased genomic instability and DNA damage responses. Previously, we found that Ku70 also inhibits Bax, a key mediator of apoptosis. We hypothesized that Bax-mediated apoptosis would be enhanced in the absence of Ku70 and contribute to premature death observed in $k u 70^{-1-}$ mice. Here, we show that $\mathrm{ku}^{-10^{-1}}$ bax ${ }^{+/-}$and $\mathrm{ku}^{-1-} \mathrm{bax}^{-/-}$mice have better survival, especially in females, than $k u 70^{-/-}$mice, even though Bax deficiency did not decrease the incidence of lymphoma observed in a Ku70-null background. Moreover, we found that $\mathrm{ku}^{-1-}$ mice develop lung diseases, like emphysema and pulmonary arterial (PA) occlusion, by 3 months of age. These lung abnormalities can trigger secondary health problems such as heart failure that may account for the poor survival of $k u 70^{-1}$ mice. Importantly, Bax deficiency appeared to delay the development of emphysema. This study suggests that enhanced Bax activity exacerbates the negative impact of Ku70 deletion. Furthermore, the underlying mechanisms of emphysema and pulmonary hypertension due to PA occlusion are not well understood, and therefore $k u 70^{-/-}$and Bax-deficient $k u 70^{-1-}$ mice may be useful models to study these diseases.

Cell Death and Disease (2015) 6, e1706; doi:10.1038/cddis.2015.11; published online 26 March 2015

Ku70 (Lupus Ku autoantigen p70) is a subunit of the Ku protein complex that plays an essential role in the nonhomologous end joining (NHEJ) pathway for DNA double-strand break (DSB) repair (reviewed in Downs and Jackson ${ }^{1}$ ). Ku70-null mice have an increased sensitivity to radiation and are defective in lymphocyte differentiation because of a lack of NHEJ-dependent DSB repair. ${ }^{2-5}$ Recent studies have shown that Ku70-null mice exhibit characteristics of premature aging, ${ }^{6}$ some of which may arise as a result of the cellular responses to increased DNA damage caused by defective DNA repair. Furthermore, increased neuronal cell death observed during the development of $\mathrm{ku}^{-1 /} \mathrm{mice}^{7}$ suggests that Ku70dependent DNA repair may be essential for cell survival during normal brain development. There is increasing evidence that Ku70 has multiple biological activities independent of its role in the nucleus as a subunit of the Ku protein complex. ${ }^{1}$

Ku70 is known to have anti-apoptotic activity by suppressing the intrinsic cell death pathway ${ }^{8}$ mediated by the pro-apoptotic $\mathrm{Bcl}-2$ family of proteins, such as Bax (Bcl-2-associated protein X) ${ }^{9,10}$ Ku70-deficient cells have increased sensitivities to apoptotic stresses that are not limited to DNA-damaging stresses, ${ }^{8,11,12}$ consistent with its anti-apoptotic activity.
Our previous studies suggest that Ku70 can interact with Bax to inhibit the conformational change required for Baxinduced apoptosis. ${ }^{8}$ To date, several studies have shown that regulating the interaction between Ku70 and Bax in the cytosol can influence the cellular sensitivity to various types of stresses. ${ }^{12-28}$ Recent studies have also shown that Ku70 can suppress apoptosis by maintaining anti-apoptotic Mcl-1 protein levels through deubiquitinization, ${ }^{29}$ suppressing Apaf-1 (apoptosis protease activation factor-1) transcription ${ }^{30}$ and inhibiting p18-Cyclin E-induced cell death produced by the caspase-dependent cleavage of cyclin E. ${ }^{17}$

To determine the physiological significance of Ku70dependent inhibition of Bax-mediated apoptosis, ku70/bax ${ }^{+/-}$and $k u 70^{-/} b^{-1 /}$ mice were generated and their phenotypes were compared with $\mathrm{ku}^{-0^{-/}} \mathrm{bax}^{+/+}$mice. In the absence of Ku70, we hypothesized that Bax-mediated apoptosis would be enhanced. We found that Bax deficiency decreased the mortality of $k u 70^{-/}$mice and improved the median and maximum age of survival. This study also provides evidence that apoptosis has a significant role in age-associated degenerative diseases in defective DNA repair mutant mice.

\footnotetext{
${ }^{1}$ Department of Medicine, School of Medicine, Case Western Reserve University, Cleveland, OH, USA; ${ }^{2}$ Department of Genetics and Genome Sciences, School of Medicine, Case Western Reserve University, Cleveland, OH, USA; ${ }^{3}$ Department of Pathology, School of Medicine, Case Western Reserve University, Cleveland, OH, USA; ${ }^{4}$ Department of Pediatrics, School of Medicine, Case Western Reserve University, Cleveland, OH, USA; ${ }^{5}$ Pulmonary and Critical Care Medicine Division and Victoria Johnson Center for Pulmonary Obstructive Research, Virginia Commonwealth University, Richmond, VA, USA; ${ }^{6}$ Department of Case Comprehensive Cancer Center, School of Medicine, Case Western Reserve University, Cleveland, OH, USA and ${ }^{7}$ Department of Molecular Medicine and Institute of Biotechnology, University of Texas Health Science Center, San Antonio, TX, USA

${ }^{*}$ Corresponding author: S Matsuyama, Department of Medicine (Hematology/Oncology Division), Case Western Reserve University, School of Medicine, Wolstein Research Building 3533, 2301 Cornell Road, Cleveland, OH 44106, USA. Tel: +1 216368 5832; Fax: +1 216368 8919; E-mail: shigemi.matsuyama@ case.edu

Abbreviations: Bax, Bcl-2-associated protein X; Ku70, Lupus Ku autoantigen p70; Ku80, Lupus Ku autoantigen p80; NHEJ, nonhomologous end joining; DSB, doublestrand break; Apaf-1, apoptosis protease activation factor-1; MEF, mouse embryonic fibroblast; PAH, pulmonary artery hypertension; vWF, von Willebrand factor; ILD, interstitial lung disease; RV, right ventricle; LV, left ventricle; MPI, myocardial perform index; TUNEL, terminal deoxynucleotidyl transferase dUTP nick end labeling Received 14.8.14; revised 24.12.14; accepted 29.12.14; Edited by RA Knight
} 


\section{Results}

Bax deficiency improves the survival and lifespan in Ku70-null mice. The $k u 70^{-1-}$ mice in this study exhibited shortened lifespans as previously reported, ${ }^{6}$ with a median survival of 26 weeks $(n=55)$. The $k u 70^{+/+}$(wild type) mice in the same cohort had a survival rate of $99.4 \%(n=355)$ at 26 weeks of age (data not shown), and it has been reported that the median lifespan of wild-type mice (C57BL/6J) is $\sim 110$ weeks. ${ }^{31}$ In comparison with $\mathrm{ku} \mathrm{O}^{-/-}$mice, the median

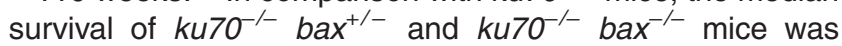
significantly longer at $37.5(n=46 ; P<0.001)$ and $38(n=23$; $P<0.01$ ) weeks, respectively (Figures $1 \mathrm{a}$ and $\mathrm{g}$ ). The maximum lifespans of $\mathrm{ku}^{-/-} \mathrm{bax}^{+/-}$(803 days, female) and $\mathrm{ku} 70^{-/} \mathrm{bax}^{-/}$(951 days, female) mice were also greater than that of $k u 70^{-1-}$ mice (656 days, female) (Figures $1 \mathrm{a}$ and $\mathrm{b})$. These results suggest that Bax deficiency was able to decrease the mortality of $k u 70^{-/}$mice that have been reported to develop premature aging phenotypes. ${ }^{2-6}$ The complete deletion of Bax may have a greater positive impact on the overall survival and lifespan of Ku70-null mice based on the lower observed mortality of $\mathrm{ku}^{-/-}$bax ${ }^{-/-}$mice compared with $\mathrm{ku}^{-1-} \mathrm{bax}^{+/-}$mice after 30 weeks of age. The extended survival because of Bax deficiency was also much more apparent in females than males (Figures $1 \mathrm{~b}$ and c). Although there were no sex-dependent differences in the lifespan of $\mathrm{ku}^{-1-}$ mice (Figure 1d), these differences became obvious in $\mathrm{ku} 70^{-/-} \mathrm{bax}^{+/-}$and $\mathrm{ku} 70^{-/-}$bax ${ }^{-/}$mice (Figures 1e-g).

Bax deficiency in Ku70-null mice leads to a slight increase in body weight and brain size. Similar to previous reports, ${ }^{6} \mathrm{ku}^{-1-}$ mice displayed growth retardation. However, the average body weight was slightly increased in ku $70^{-/-} \mathrm{bax}^{+/-}$and $k u 70^{-1-} \mathrm{bax}^{-/-}$mice (Figures 2a-c). To determine whether Bax deficiency affected specific organs to increase the overall body weight, we measured the weights of the kidneys and brain (Figures $2 d$ and e). We found that the average weights of the kidneys in $\mathrm{ku}^{-0^{-}-} \mathrm{bax}^{+/-}$and $\mathrm{ku} 7 \mathrm{O}^{-/-}$ $b_{a x}{ }^{-/-}$mice were not significantly increased compared with $k u 70^{-1-}$ mice (Figure 2d). However, the average brain weight was significantly increased in $k u 70^{-1-}$ bax $^{-1-}(P<0.0001)$ mice, and to a lesser extent in $k u 70^{-/-}$bax $^{+/-}(P<0.05)$ mice (Figure 2e), even though $\mathrm{ku} \mathrm{O}^{-/-} \mathrm{bax}^{+/-}$and $\mathrm{ku} 70^{-/-} \mathrm{bax}^{-/-}$ mice have similar extended survival. This suggests that changes in brain size may not necessarily alter lifespan. Baxnull mice are known to have increased brain weight (Figure 2e) because of the suppression of neuronal cell death during development ${ }^{32}$, whereas $k u 70^{-1-}$ mice exhibit increased neuronal cell death. ${ }^{7}$ The effects of Bax deletion on the brain weight in Ku70-null mice in this study are consistent with these previous reports.

Previous studies have reported that $k u 70^{-/}$mice have decreased lymphocyte counts because of deficient lymphocyte differentiation caused by the absence of NHEJdependent T-cell and B-cell receptor maturation. ${ }^{2-5}$ Our blood cell count measurements were consistent with these findings (Figures 2f-j). The number of neutrophils was increased in ku $70^{-/}$mice (Figure $2 \mathrm{~g}$ ), most likely to compensate for the decrease in lymphocytes (Figure $2 \mathrm{~h}$ ). Bax deficiency did not significantly affect the overall number of white and red blood cells and platelets in Ku70-null mice (Figures 2f, i, and j).

Bax deficiency in Ku70-null MEFs decreases apoptosis sensitivity but does not affect cellular senescence in vitro. Ku70-null and Bax mutant mouse embryonic fibroblasts (MEFs) were used to determine whether cell death susceptibility could be attenuated by Bax deficiency (Figures $3 a-c)$. As previously reported, 8,12,16,33 $\mathrm{ku}^{-1-}$ MEFs show increased sensitivity to Doxorubicin, which induces DNA damage and activates Bax-mediated apoptosis. We confirmed that Bax deficiency attenuated cell death induction by Doxorubicin treatment in $\mathrm{ku}^{-0^{-/}} \mathrm{bax}^{+/-}$and $k u 70^{-1-} \mathrm{bax}^{-/-}$MEFs (Figures $3 \mathrm{~b}$ and c). We further examined whether Bax deficiency influences cellular senescence in $\mathrm{ku} 7 \mathrm{O}^{-/-} \mathrm{bax}^{+/-}$and $\mathrm{ku} 70^{-/-} \mathrm{bax}^{-/-}$MEFs (Figures $3 \mathrm{~d}$ and e). As previously reported, ${ }^{34} \mathrm{ku}^{-1} \mathrm{O}^{-1}$ MEFs undergo fewer passages and reach cellular senescence earlier than wild-type MEFs (Figure 3d). Bax deficiency did not show a significant effect on cellular senescence in $\mathrm{ku}^{-/-} \mathrm{bax}^{+/-}$ and $\mathrm{ku} 7 \mathrm{O}^{-/-} \mathrm{bax}^{-/-}$MEFs based on decreased cell counts after multiple passages (Figure $3 d$ ) and similar senescence associated $\beta$-galactosidase staining as $k u 70^{-1}$ MEFs (Figure 3e).

Cancer incidence and abnormalities in moribund or dead mice. Almost one-third (28.6\%) of $\mathrm{ku}^{-1-} \mathrm{O}^{-1}$ mice developed thymic tumors or disseminated lymphoma with splenomegaly and hepatomegaly (Table 1 and Supplementary Figure S1). A slight difference in the development of lymphoma was observed between $k u 70^{-/}$males $(27.3 \%, \quad n=33)$ and females (33.3\%, $n=21)$ (Supplementary Table S1). Two other independent studies previously reported T-cell lymphomas in $\mathrm{ku} 70^{-1-} \mathrm{C} 57 \mathrm{BL} / 6 \mathrm{~J}$ mice, ${ }^{3,4}$ but not in the $129 \times \mathrm{C} 57 \mathrm{BL} / 6$ strain, ${ }^{6}$ suggesting that the development of T-cell lymphoma is strain dependent. In the $k u 70^{-/}$bax ${ }^{+/-}$mice, the incidence of lymphoma was similar to that of $k u 70^{-1-}$ mice in both males $(27.3 \%, n=22)$ and females $(30.4 \%, n=23)$ (Supplementary Table S1), despite having an extended survival. Male $\mathrm{ku} \mathrm{O}^{-/}$bax $\mathrm{x}^{-/}$mice also had a similar incidence of lymphoma (25\%, n=12) to $k u 70^{-1-}$ and $\mathrm{ku} 7 \mathrm{O}^{-/} \mathrm{bax}^{+/-}$mice. However, $55.6 \%$ of the female $\mathrm{ku} 7 \mathrm{O}^{-/}$ $\mathrm{bax}^{-/-}$mice $(n=9)$ developed lymphoma compared with ku $70^{-/-}$and $\mathrm{ku} 7 \mathrm{O}^{-/-} \mathrm{bax}^{+/-}$mice (Supplementary Table S1), but this increased incidence may be because of the longer lifespan observed in $k u 70^{-/-}$bax ${ }^{-/-}$females.

$K u 70^{-1-}$ mice also developed rectal prolapse (12.5\%) and abnormal teeth (19.7\%) (Table 1). In the $k u 70^{-1-}$ mice with abnormal teeth, we observed malocclusion (misaligned teeth) in mice that died at a young age $(n=3)$ (Table 1 and Supplementary Figure S2). Malocclusion at a young age, especially shortly after weaning, can impair the ability to eat, making these mice more prone to starvation and malnutrition (Supplementary Figure S2, see $k u 70^{-/}$mice (52 days)). In addition, we observed abnormally long teeth in adult $k u 70^{-1}$ mice $(n=8)$ that likely occurred as a result of a decrease in gnawing behavior due to other underlying illness. For example, one of the $\mathrm{ku} \mathrm{r} \mathrm{O}^{-1}$ mice (130 days old) (Supplementary Figure S2) was found to have severe lung necrosis and abnormal cardiac hypertrophy at the 
a

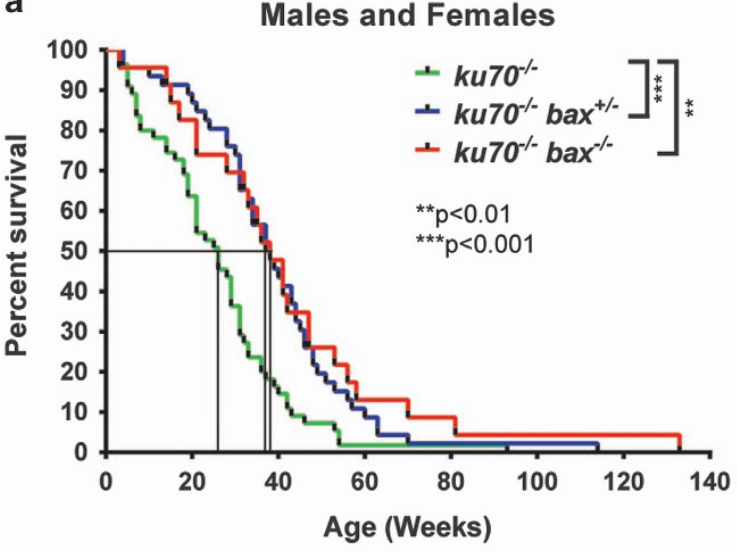

b

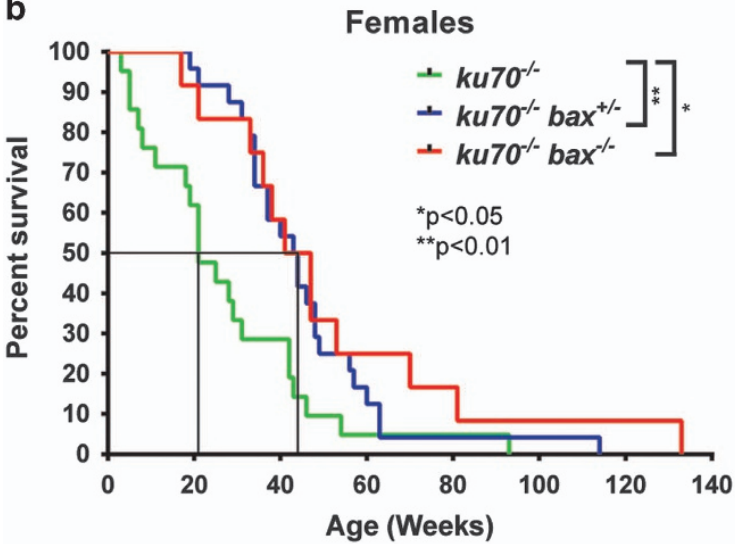

c

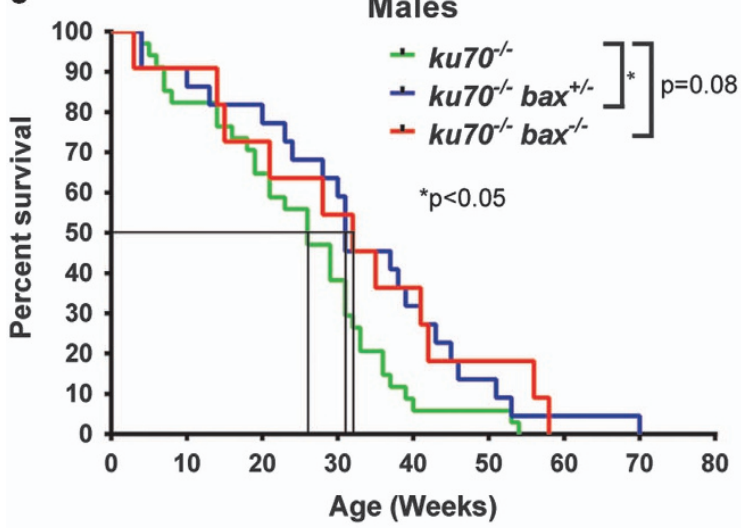

d

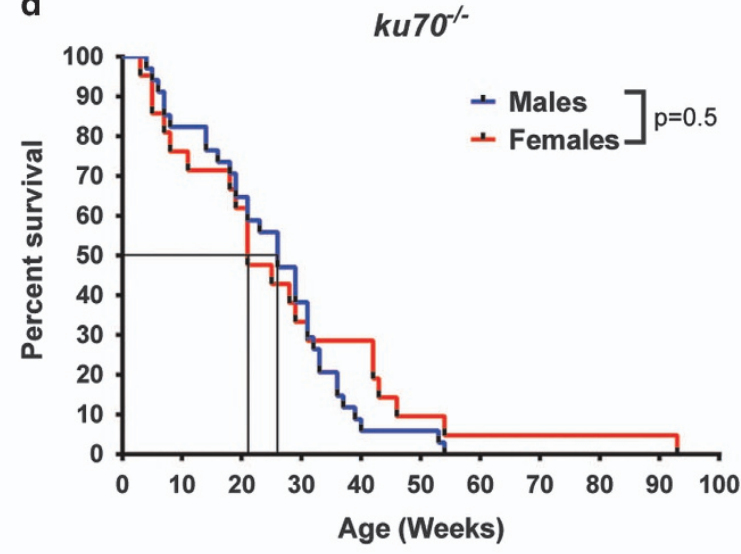

e

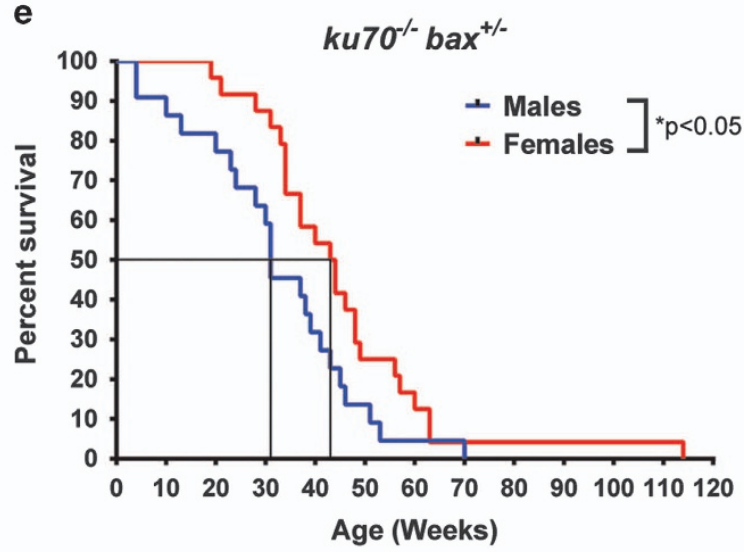

f

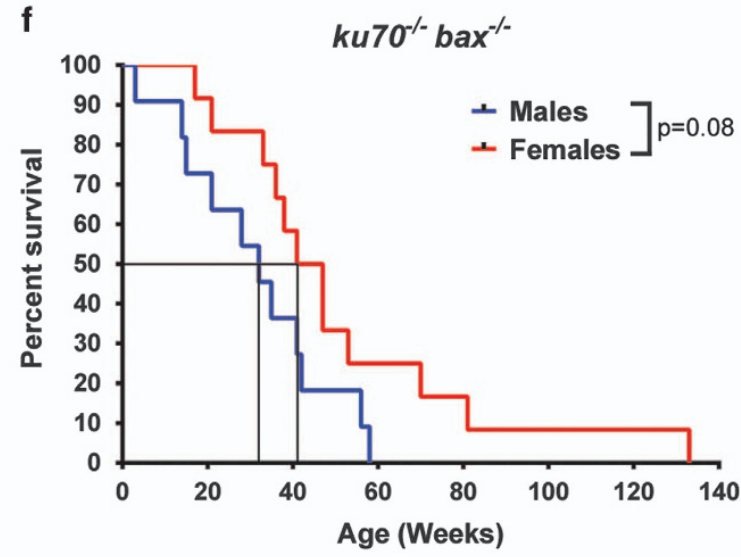

\begin{tabular}{|c|c|c|c|}
\hline \multicolumn{4}{|c|}{ Median Survival (weeks) } \\
\hline Genotype & Total & Females & Males \\
\hline ku $70^{-/-}$ & $26(n=55)$ & $21(\mathrm{n}=21)$ & $26(n=34)$ \\
\hline $\boldsymbol{k u} 70^{-/-} \boldsymbol{b a x}^{+/-}$ & $37.5(n=46)$ & $43.5(n=23)$ & $31(n=23)$ \\
\hline ku $70^{-/} \boldsymbol{b a x}^{-/-}$ & $38(n=23)$ & $44(n=12)$ & $32(\mathrm{n}=11)$ \\
\hline
\end{tabular}

Figure 1 Bax deficiency improved the survival and extended the lifespan of Ku70-null mice. Kaplan-Meier survival curves are shown for (a) all mice analyzed, (b) females, and (c) males. Sex-specific survival are shown for (d) $k u 70^{--}$, (e) $k u 70^{-/-} \mathrm{bax}^{+/-}$, and (f) $k u 70^{-/-} \mathrm{bax}^{-/-}$. (g) The table summarizes the median survival of all mice analyzed 
a

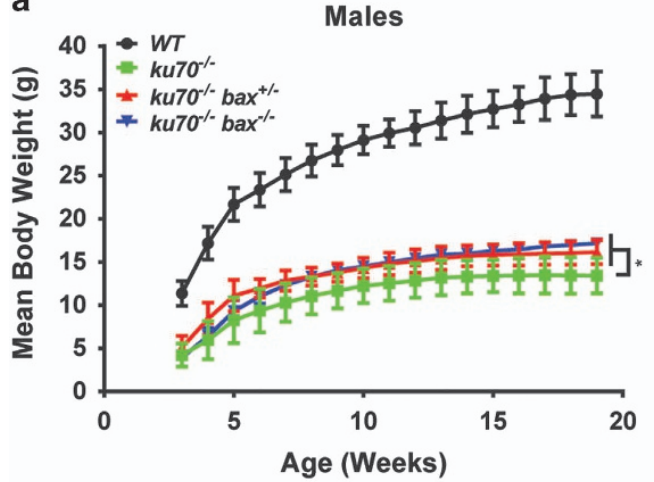

b

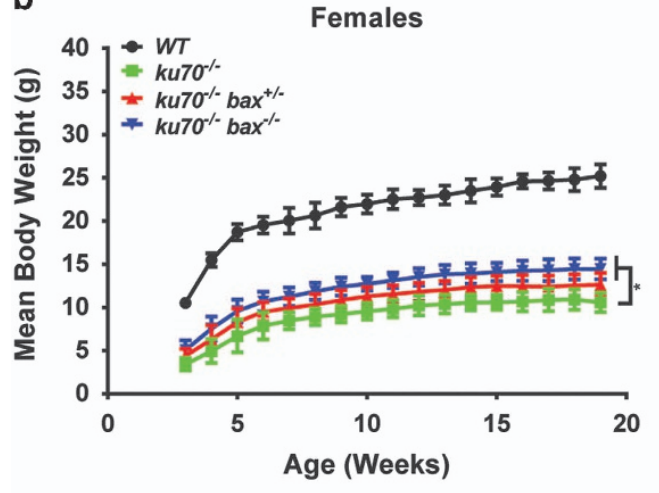

c
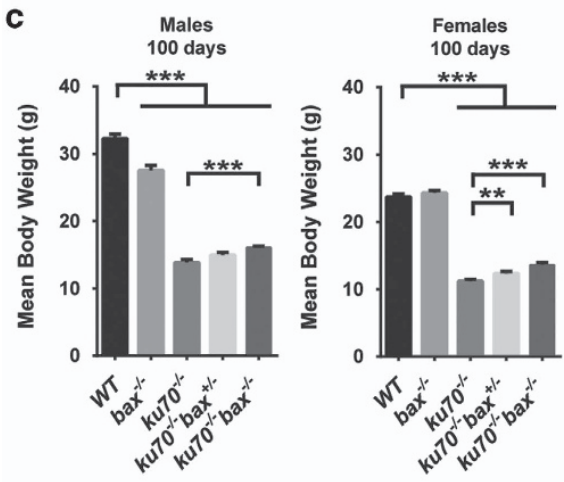

d

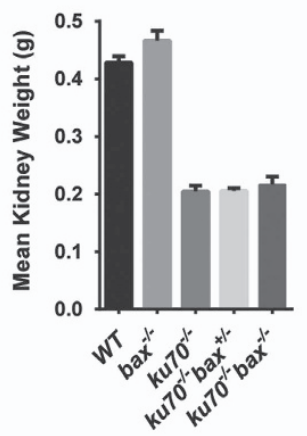

f

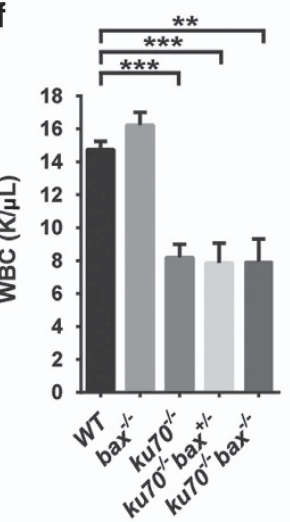

i

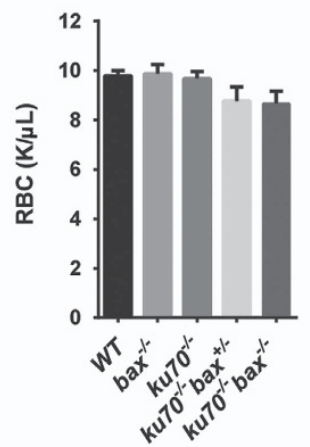

e

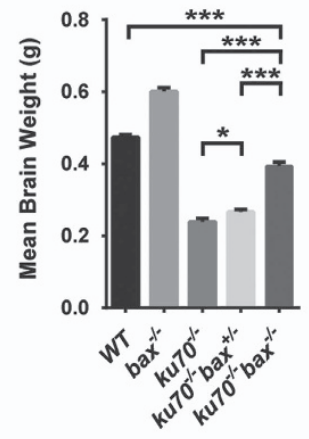

g

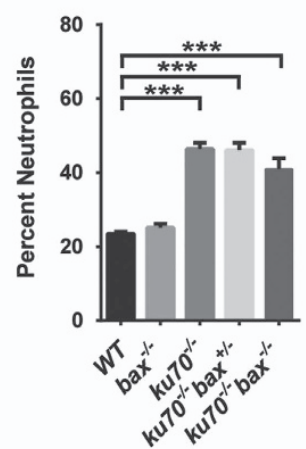

h

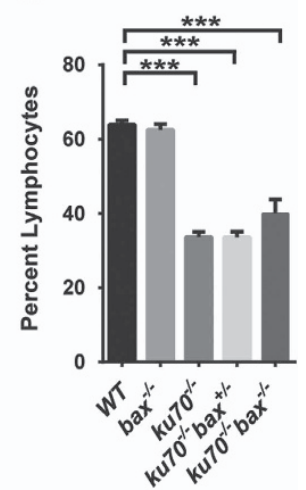

j

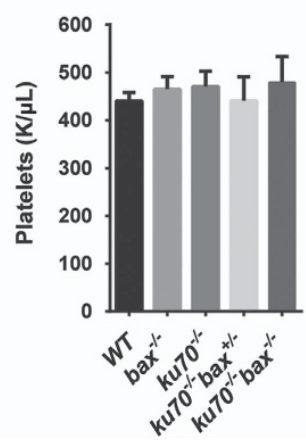

Figure 2 Growth curves, organ weights, and hematocrit analyses. (a and $\mathbf{b})$ The growth curves shown are based on the average body weights measured in (a) male WT

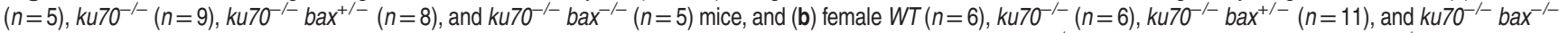
$(n=6)$ mice. (c) The mean body weights are shown for 100 days of age for $W T$ (males $n=11$; females $n=10$ ), bax ${ }^{-/}$(males $n=7$; females $n=3$ ), ku70 (males $n=17$; females $n=13$ ), $\mathrm{ku}^{-1-} \mathrm{bax}^{+-}$(males $n=7$; females $n=17$ ), and $\mathrm{ku}^{-{ }^{-1}}$ bax ${ }^{-1-}$ (males $n=7$; females $n=9$ ) mice. The average weights are shown for (d) kidney in $W T$

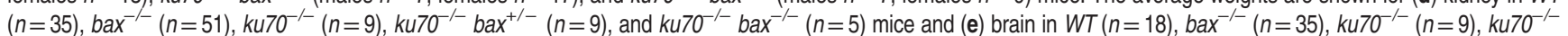
bax $^{+--}(n=12)$, and ku70 ${ }^{-/-}$bax $^{-/-}(n=5)$ mice. (f-j) Hematocrit quantification of (f) WBCs and the percent composition of $(\mathbf{g})$ neutrophils and (h) lymphocytes, (i) RBCs, and

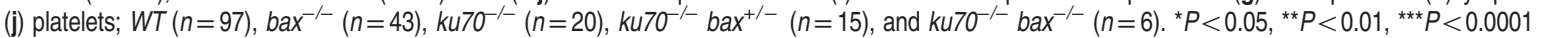

time of death. The incidence of abnormal teeth was lower in Bax-deficient Ku70-null mice (Table 1), and this difference may contribute to their improved survival. When we analyzed survival, excluding malocclusion, the median lifespan of Bax-deficient Ku70-null mice remained greater than ku $7 \mathrm{O}^{-/}$mice (Supplementary Figure S3). Therefore, it is likely that other health effects besides the decreased teeth impairment from Bax deficiency are contributing to enhanced survival.
Approximately half of all of the dead mutant mice were not analyzed for the cause of death because of bodily damage caused by other mice or excessive post-mortem necrosis. These mice are listed under 'unknown cause of death' in Table 1. We suspect that some of these mice developed lymphoma or other diseases, including defects in the heart and lungs, which is discussed below. Therefore, the actual occurrence rate of these diseases may be higher than the rate that was confirmed by analyses of fresh samples. In addition, 

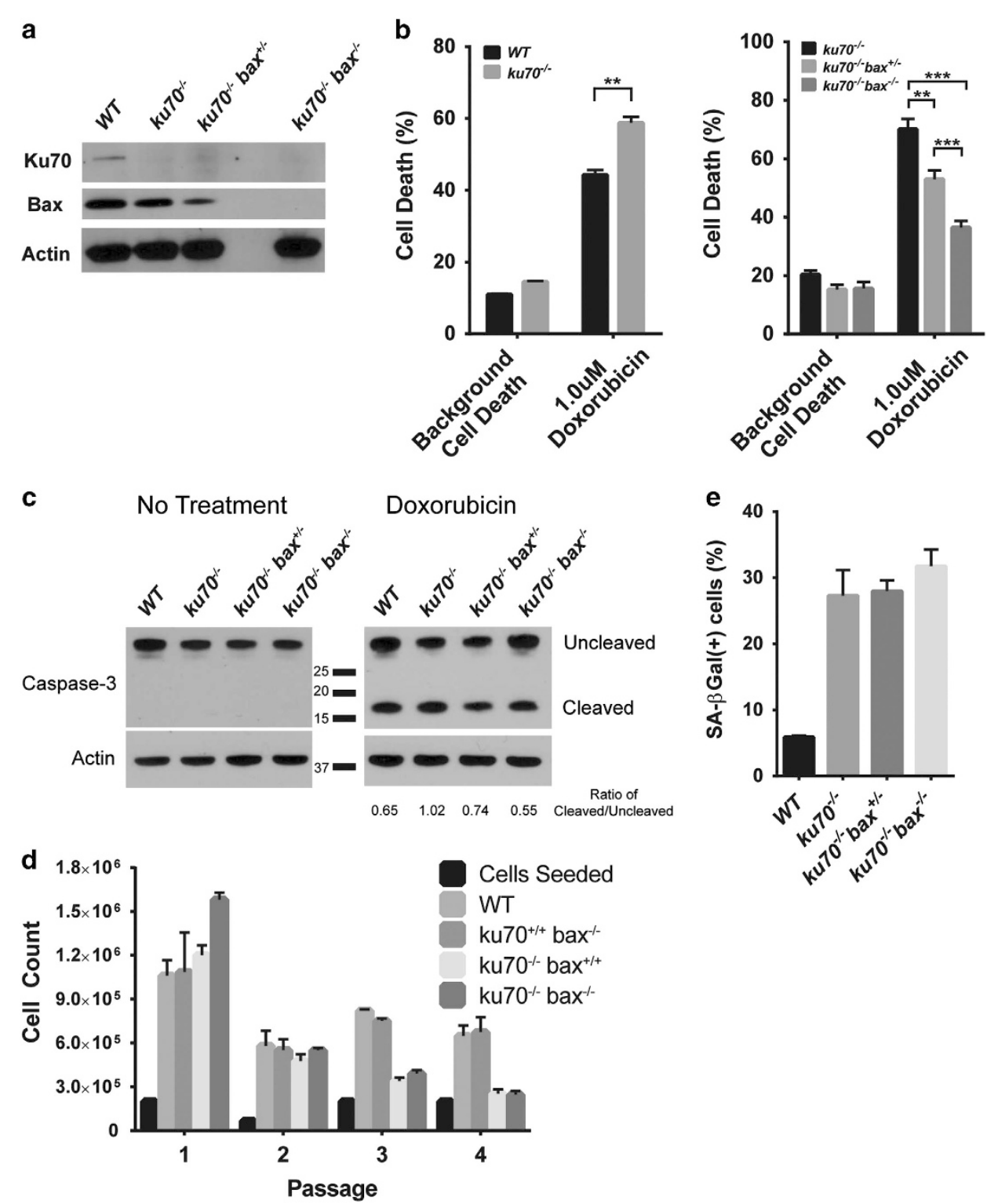

Figure 3 Bax deficiency reduced $k 470^{-1-}$ MEF sensitivity to apoptosis but not cellular senescence. (a) Immunoblots of MEFs showing the protein expression levels of Ku70, Bax, and actin. (b) In comparison with WT, ku70 ${ }^{-1}$ MEFs showed increased apoptosis sensitivity to Doxorubicin, whereas Bax-deficient Ku70-null MEFs displayed decreased Doxorubicin-induced apoptosis $(n=4)$. (c) Doxorubicin treatment led to Caspase-3 cleavage. Densimetric analyses are shown for independent experiments $(n=2)$. Based on (d) cell counts after each passage $(n=4)$ and the quantification of $(e)$ senescence-associated $\beta$-galactosidase staining $(n=4)$, Bax deficiency did not delay cellular senescence in Ku70-null MEFs. ${ }^{* \star} P<0.01,{ }^{* \star *} P<0.0001$

Table 1 Macroscopic abnormalities found in moribund/dead mice

\begin{tabular}{|c|c|c|c|c|c|c|c|c|}
\hline \multirow[t]{3}{*}{ Genotype } & \multirow[t]{3}{*}{ Total } & \multicolumn{3}{|c|}{ Lymphoma } & \multicolumn{3}{|c|}{ Abnormalities found in: } & \multirow[t]{3}{*}{ Unknown cause of death } \\
\hline & & \multirow[t]{2}{*}{ Thymic } & \multirow[t]{2}{*}{ Disseminated } & \multirow[t]{2}{*}{ Total } & \multirow[t]{2}{*}{ Rectum } & \multicolumn{2}{|c|}{ Teeth } & \\
\hline & & & & & & Malocclusion & Long/thick teeth & \\
\hline $\begin{array}{l}\text { ku } 70^{-/} \\
\text {ku } 70^{-1-} \text { bax }^{+/-} \\
\text {ku } 70^{-/-} \text {bax }^{-/-}\end{array}$ & $\begin{array}{l}56 \\
45 \\
21\end{array}$ & $\begin{array}{r}13 \\
12 \\
8\end{array}$ & $\begin{array}{l}3 \\
1 \\
0\end{array}$ & $\begin{array}{r}16(28.6 \%) \\
13(28.9 \%) \\
8(38.1 \%)\end{array}$ & $\begin{array}{c}7(12.5 \%) \\
4(8.9 \%) \\
0\end{array}$ & $\begin{array}{c}3(5.4 \%) \\
0 \\
0\end{array}$ & $\begin{array}{c}8(14.3 \%) \\
3(6.7 \%) \\
0\end{array}$ & $\begin{array}{l}24(42.9 \%) \\
27(60 \%) \\
13(61.9 \%)\end{array}$ \\
\hline
\end{tabular}


a
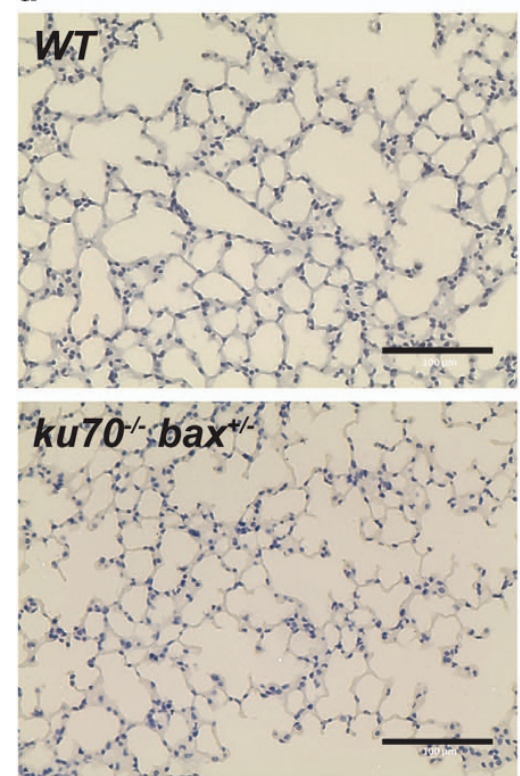
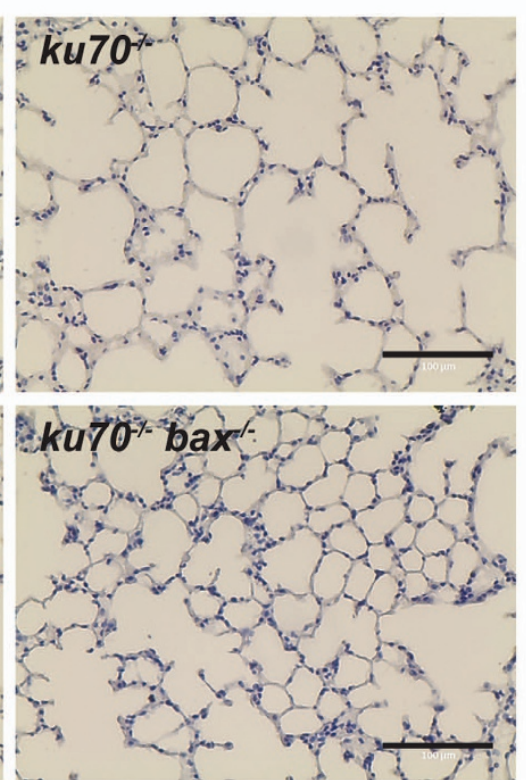

b

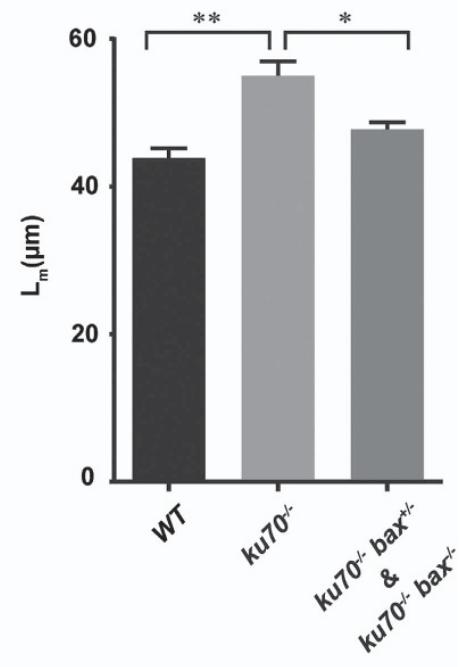

Figure 4 Emphysema was identified as a potential cause of premature death in $k u 70^{-/}$mice. (a) Representative lung tissue sections of 100-day-old mice show that ku70 $0^{-1}$ mice developed enlarged alveolar spaces, indicative of emphysema. Bax deficiency was able to delay the onset of emphysema in Ku70-null mice. (b) Calculations of mean length intercept $\left(L_{m}\right)$ were determined to measure the differences in alveolar sizes. WT $(n=9), k u 0^{-/-}(n=7), k u 70^{-/-}$bax $^{+/-}(n=2)$, and $k u 70^{-/-}$bax $^{-/-}(n=2) ;{ }^{*} P<0.05,{ }^{* *} P<0.001$

infectious diseases may also account for the death in the unknown group as seen in Ku80 (Lupus Ku autoantigen p80) knockout mice. $^{35}$

Aging-related changes detected by macroscopic analysis. Ku70-deficient mice develop age-associated changes, such as kyphosis and alopecia, earlier than normal. ${ }^{6}$ Interestingly, Bax deficiency delayed the development of some of these age-associated changes in Ku70-null mice (Supplementary Table S2). Furthermore, $\mathrm{ku}^{-1} \mathrm{O}^{-1}$ mice older than 6 months old did not have visually detectable subcutaneous fat, consistent with the disappearance of subcutaneous fat reported in prematurely aging mice with mutant A-type lamins. ${ }^{36,37}$ Bax-deficient Ku70-null mice of the same age maintained this fat layer (Supplementary Table S2). Altogether, these results suggest that the absence of Baxmediated apoptosis can slow down the progression of organismal aging and loss of subcutaneous fat in Ku70null mice.

Ku70-null mice develop lung abnormalities. Structural and vascular abnormalities were detected in the lungs of ku $70^{-/-}$mice (Figures 4 and 5 and Supplementary Figures S4 and S7). The diseases found in the lungs include emphysema (Figure 4), pulmonary arterial occlusion (Figure 5), and interstitial lung disease (Supplementary Figure S7), all of which can induce hypoxia and contribute to heart failure. Emphysema is caused by excessive lung epithelial cell death that results in the enlargement of the alveolar space. ${ }^{38,39}$ Ku70-deficient alveolar epithelial cells have been shown to be hypersensitive to DNA damages ${ }^{40,41}$ caused by DNA synthesis errors and reactive oxygen species (ROS). Based on histological analyses and mean length intercept measurements in 3-4-month-old mice (Figure 4), $k u 70^{-1-}$ mice had significantly larger alveolar space than wild-type mice (Figure 4b). Interestingly, the size of the alveolar space in 3-4-month-old $\mathrm{ku}^{-1} \mathrm{O}^{--} \mathrm{bax}^{+/-}$and $\mathrm{ku} 7 \mathrm{O}^{-/}$ $\mathrm{bax}^{-1-}$ mice were similar to that of wild type (Figure $4 \mathrm{~b}$ ), suggesting that the absence of Bax-mediated apoptosis can attenuate the development of emphysema in Ku70-null mice. The delayed onset of emphysema may be another factor in the improved survival rate in Bax-deficient Ku70-null mice. In fact, numerous TUNEL (terminal deoxynucleotidyl transferase dUTP nick end labeling)-positive cells were detected in a third of the $\mathrm{ku} \mathrm{70^{-1 }}$ mice examined $(n=6)$, whereas apoptotic cells were hardly detected in wild-type $(n=8)$ and $k u 70^{-1}$ $b a x^{-1-}$ mice $(n=6)$ (Supplementary Figure S4). Because we were not able to detect an abnormally large number of dying pulmonary cells in the other two-thirds of the $\mathrm{ku} \mathrm{-1}-\mathrm{-}$ mice, we speculate that apoptotic cells are hard to detect in vivo, unlike in cell culture experiments, since dead cells can be cleared by macrophages and neighboring cells, especially if the $k u 70^{-1}$ mice were in the stages of developing lung diseases.

Pulmonary arterial occlusions can lead to pulmonary arterial hypertension (PAH). Blood vessel occlusions were detected by staining the pulmonary arteries with an endothelial cell marker, von Willebrand factor (vWF) (Figure 5). ${ }^{42}$ Occluded pulmonary arteries were observed in $\mathrm{ku}^{-1-}$ mice and may be because of abnormal endothelial cell overgrowth (Figure 5b). Plexiform-like lesions surrounding the occluded blood vessels were also observed in $\mathrm{ku}^{-1} \mathrm{O}^{-/}$mice (Figure $5 \mathrm{~b}$, circled). Almost half of the $k u 70^{-1}$ mice analyzed (42.9\%) developed pulmonary vessel occlusions. However, Bax deficiency did not dramatically attenuate the incidence of these abnormalities (Figure $5 \mathrm{c}$ ), suggesting that the extended survival of Bax-deficient Ku70-null mice was not mainly 
a

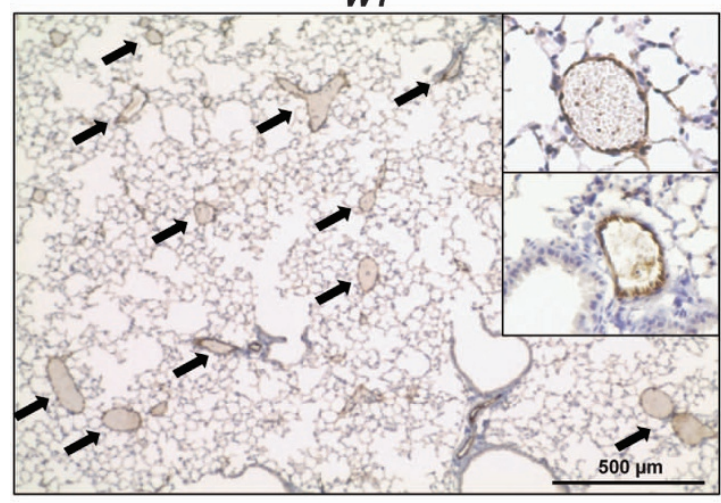

b

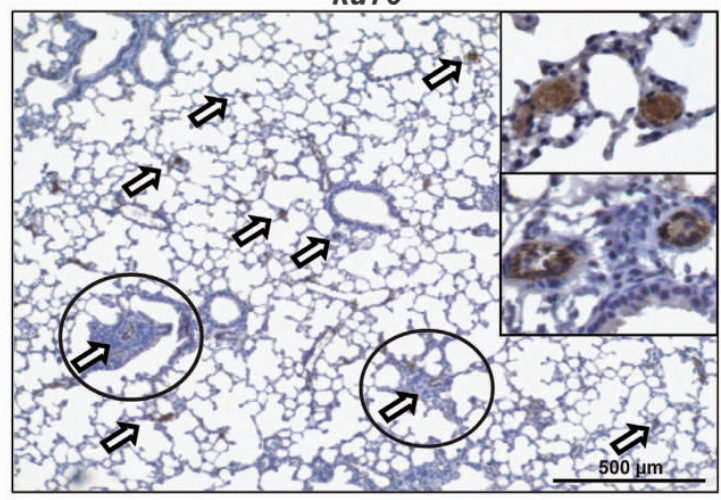

\begin{tabular}{l|c}
\hline \multicolumn{1}{c|}{ Genotype } & $\begin{array}{c}\text { Blood Vessel } \\
\text { Occlusion }\end{array}$ \\
\hline $\boldsymbol{W} \boldsymbol{T}$ & $0 / 13$ \\
$\boldsymbol{b} \boldsymbol{a} x^{-/}$ & $0 / 8$ \\
$\boldsymbol{k} \boldsymbol{u} 70^{-/}$ & $6 / 14(42.9 \%)$ \\
$\boldsymbol{k} \boldsymbol{u} 7 \boldsymbol{0}^{-/} \boldsymbol{b a x}^{+/}$ & $2 / 7(28.6 \%)$ \\
$\boldsymbol{k} \boldsymbol{u} 7 \boldsymbol{0}^{-/} \boldsymbol{b a x}^{-/}$ & $2 / 6(33 \%)$
\end{tabular}

Figure 5 Blood vessel occlusions were found in the lungs of 100-day-old $k u 70^{-/-}$mice. Immunohistochemical staining with the endothelial cell marker, von Willebrand Factor (vWF), in (a) WT and (B) $k u 70^{-1-}$ showed the presence of pulmonary arterial occlusions only in $k u 70^{-1-}$ mice. $K u 70^{-1-}$ mice also developed plexiform-like lesions around the occluded vessel (circled). (c) The table summarizes the number of mice in each genetic background that developed blood vessel occlusion by 100 days of age

because of the prevention of PAH. Interestingly, a previous microarray gene expression study of lung tissue from patients with idiopathic PAH showed decreased Ku70 expression in 5 out of 6 patients. ${ }^{43}$ Our findings of pulmonary arterial occlusion in $k u 70^{-1-}$ mice could provide clues to help understand the mechanism underlying PAH.

Interstitial lung disease (ILD) was also observed in our mutant mice (Supplementary Figure S7). ILD is defined by an invasion of interstitial cells into the alveolar space and can result from different mechanisms, such as fibrosis, inflammation, or abnormal growth of lung epithelial cells. ${ }^{44}$ ILD was found more frequently in Bax-deficient Ku70-null mice than in $k u 70^{-1}$ mice (Supplementary Figure S7D). However, ILD in these mice was not a result of fibrosis, excessive collagen deposition, or excessive smooth muscle growth, based on Masson's trichrome staining (Supplementary Figure S7A). In addition, ILD was not caused by inflammation or cancer as there was no accumulation of CD45-positive cells (a marker for leukocytes) or Ki67-positive cells, typical of dividing cancer cells (Supplementary Figure S7A-B). Type 1 and 2 alveolar epithelial cells were found in the regions of ILD (Supplementary Figure S7C), suggesting that this ILD, which destroyed alveolar structure, was caused by the abnormal growth and distribution of these cell types. ILD also progressed in an age-dependent manner as severe ILD was found more often in mice $>6$ months of age.

Bax deficiency can attenuate cardiac defects in Ku70-null mice. Multiple signs of cardiac dysfunction were present in $k u 70^{-1}$ mice. Enlargement of the right ventricle (RV) was observed in $k u 70^{-1-}$ mice by 7 months of age (Figure 6a;
Supplementary Figure S6, arrows). Echocardiographic measurements of 4-6- month-old mice confirmed the presence of functional abnormalities in $k u 70^{-1-}$ mice (Figure $6 \mathrm{~b}-\mathrm{d}$ ). The myocardial performance index (MPI), a measure of systolic and diastolic function, ${ }^{45}$ was determined for both the RV and left ventricle (LV), and values near 0.32 are considered normal. The MPI values for $k u 70^{-1}$ mice were normal for the LV but was abnormal for the RV (Figure 6b). Longitudinal strain at the basal and mid-regions of the RV were measured to assess contractility. ${ }^{34}$ Ku70-null mice showed significantly lower absolute RV strain, and thus less contractility, compared with wild-type mice (Figure 6c). Furthermore, there was a greater pressure load in the pulmonary artery in $k u 70^{-1}$ mice than in the wild-type mice, based on the shorter Doppler-determined acceleration time of blood flow through the pulmonary artery (Figure 6d). Our preliminary experiment showed that $\mathrm{ku}_{70^{--}} \mathrm{bax}^{-/-}$mice had higher RV MPI than wild-type mice (in this preliminary experiment, all mice were analyzed on the same day under similar conditions, RV MPIs were $0.401 \pm 0.018$ (wild type),

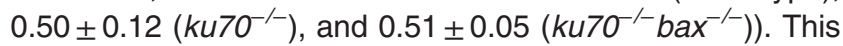
observation suggests that Bax deficiency was not able to normalize heart function in $k u 70^{-/}$mice. However, this preliminary measurement was performed only once because of the difficulties with obtaining enough $k u 70^{-1}$ and $k u 70^{-1}$ $\mathrm{bax}^{-/}$mice for simultaneous comparative measurements. Therefore, further detailed analysis using $\mathrm{ku}^{-\mathrm{O}^{-/}} \mathrm{bax}^{-/}$ mice will be necessary to understand the mechanism of how Bax deletion can delay the onset of fatal heart failure in ku $70^{-/-}$mice. 
a
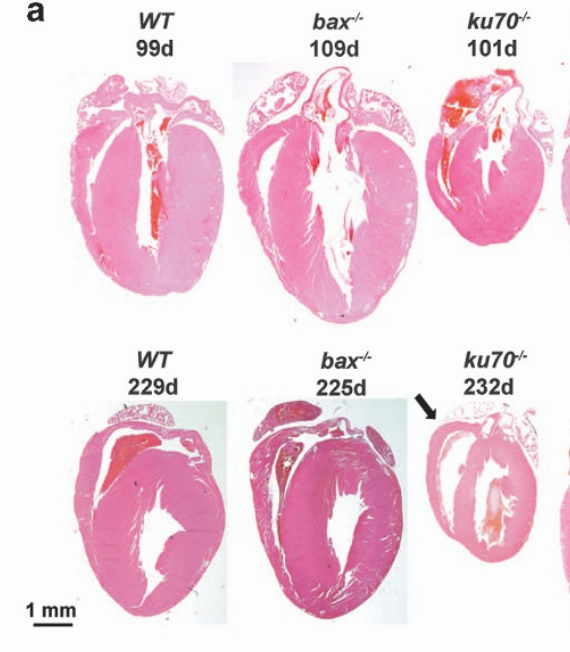

b

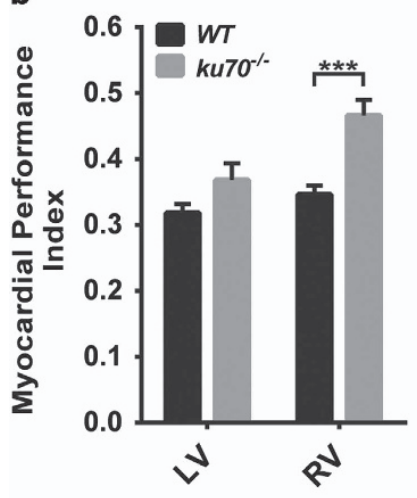

c

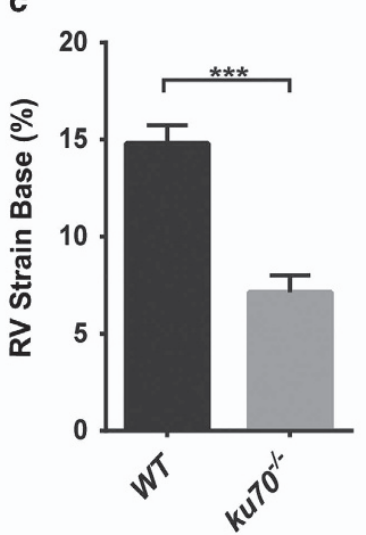

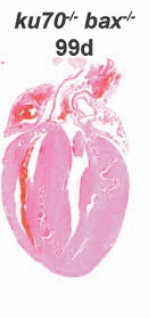

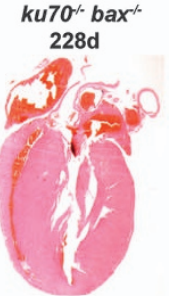

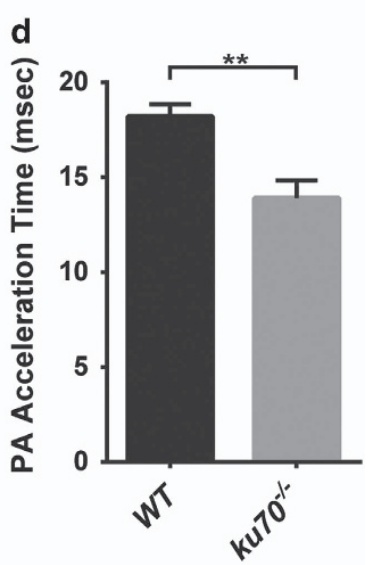

Figure 6 Cardiac histological and functional analyses. (a) Comparison of the hearts in a 4-chamber view is shown. H\&E staining of representative hearts show structural

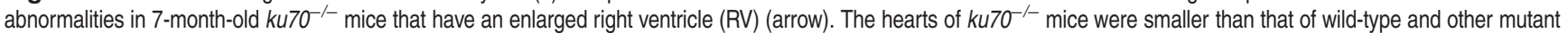
mice. (b-d) Echocardiographic analyses of 4-6-month old WT $(n=10)$ and $k u 70^{-1-}(n=10)$ mice show that ku70 ${ }^{-1-}$ mice had (b) abnormal RV function, whereas left ventricular (LV) function is normal $(P=0.1)$. A myocardial performance index (MPI) value $>0.40$ suggests that there is abnormal systolic and/or diastolic function. (c) Decreased strain in the basal region of the $\mathrm{RV}$ in $\mathrm{ku} \mathrm{O}^{-/-}$and (d) shorter pulmonary artery acceleration time suggest reduced muscle contractility and higher pressure load in the pulmonary arteries, respectively. ${ }^{* *} P<0.01,{ }^{* * *} P<0.0001$

Despite being slightly larger in body size than $\mathrm{ku}^{-1 /}$ mice (Figures 2a-c), $\mathrm{ku}^{-/-} \mathrm{bax}^{-/-}$mice had disproportionately larger hearts (Figure 6a and Supplementary Figure S6). Based on histological analysis, the RVs in $\mathrm{ku}^{-1-} \mathrm{bax}^{-/-}$mice were not as dilated compared with $k u 70^{-1}$ mice (Figure $6 \mathrm{a}$ and Supplementary Figure S6), suggesting that the hearts of Bax-deficient Ku70-null mice may be able to tolerate stresses caused by the absence of Ku70 (e.g., DNA damage). We performed TUNEL staining, but we were not able to detect dying cells in the hearts collected from actively moving mice (Supplementary Figure S5). We speculate that, unlike in in vitro settings, the rapid clearance of apoptotic cells in vivo makes it difficult to detect the actual accumulation of dead cells.

Bax deficiency did not reduce the DNA damage load in Ku70-null brains. Ku70 deficiency has been shown to decrease neuronal survival during development because of excessive neuronal apoptosis, ${ }^{7}$ whereas Bax deficiency has the opposite effect. ${ }^{32}$ When compared with wild-type mice, the overall brain size and weight of $k u 70^{-/}$mice were smaller whereas $\mathrm{bax}^{-/}$brains were larger (Figure 2e), and the number of hippocampal neurons showed a similar trend (Supplementary Figure S8A). Interestingly, ku70 ${ }^{-/}$ bax ${ }^{+/-}$brains were only slightly heavier than $k u 70^{-/}$ brains, even though $k u 70^{-/-}$bax ${ }^{+/-}$mice showed extended survival similar to the $\mathrm{ku}^{-1-} \mathrm{bax}^{-/}$mice (Figures 1 and 2e). $K u 70^{-1}$ mice showed increased DNA DSBs in the hippocampus, based on phospho- $\gamma \mathrm{H} 2 \mathrm{~A}$.X staining (Supplementary Figures S8B and C). The neurons in $k u 70^{-/-} \mathrm{bax}^{+/-}$and $\mathrm{ku} 7 \mathrm{O}^{-/-} \mathrm{bax}^{-/-}$mice were also positive for phospho- $\gamma \mathrm{H} 2 \mathrm{~A} . \mathrm{X}$; therefore, Bax deficiency did not help improve neuronal DNA damage repair despite its role in increasing the survival of these neurons.

Bax deficiency in Ku70-null mice did not lead to abnormalities in the kidneys and liver. Unlike the lungs, heart, and brain, the kidneys and liver exhibited no obvious histological defects in both Ku70-null mice and Baxdeficient Ku70-null mice (Supplementary Figures S9 and S10). Based on Masson's trichrome staining, none of the mice 
analyzed developed liver fibrosis (Supplementary Figure S10A). The amount of DNA DSBs in the kidneys (Supplementary Figures S9A and D) and liver (Supplementary Figures $\mathrm{S} 10 \mathrm{~B}$ and $\mathrm{E})$ at 3 months of age was similar across all genetic groups. Bax deficiency did not lead to excessive cell growth or tumorigenesis in the kidneys (Supplementary Figures S9B and E) and liver (Supplementary Figures S10C and F) based on Ki67 staining. Furthermore, to determine whether there were differences in the occurrence of apoptosis, cleaved Caspase-3 staining was performed (Supplementary Figures S9C and S10D). However, there are very few detectable Caspase 3-positive cells in these tissues, most likely because of the rapid clearance of apoptotic cells.

\section{Discussion}

Previous studies have shown that Ku70 has anti-apoptotic activity by suppressing the intrinsic cell death signal mediated by Bax, in addition to its role in NHEJ DNA DSB repair. ${ }^{8}$ Our results support the hypothesis that the absence of Ku70 leads to Bax hyperactivation, giving rise to the development of degenerative diseases that culminate in an early death in $k u 70^{-1-}$ mice. Furthermore, the increased accumulation of DNA damage because of the absence of Ku70 can also trigger the DNA damage response to indirectly initiate apoptosis through p53-dependent Bax activation. ${ }^{46}$ We suspect that both of these mechanisms of Bax activation are contributing to the premature death observed in $\mathrm{ku} \mathrm{O}^{-1}$ mice.

In other previous studies, $k u 70^{-/} p 53^{-1-}$ and $k u 80^{-1-}$ $p 53^{-1-}$ mice developed tumors at much higher frequencies than single Ku70 or Ku80 knockout mice. ${ }^{47,48}$ These observations indicate that NHEJ deficiency can cause oncogenic mutations and that p53-dependent cellular responses, such as cell cycle arrest and apoptosis, are important to suppress tumorigenesis. As p53 is intact in Baxdeficient Ku70-null mice, we speculate that p53 is able to suppress tumorigenesis caused by deficient NHEJ through p21-mediated cell cycle arrest and cellular senescence. Previous reports also show that cell cycle arrest, including cellular senescence, plays a greater role than apoptosis to suppress tumorigenesis in NHEJ-deficient mice. ${ }^{49,50}$ Consistent with these findings, this study shows extended survival in male and female $k u 70^{-1-}$ bax $^{+/-}$mice and male $k u 70^{-1-}$ $\mathrm{bax}^{-/-}$mice without a significant increase in the incidence of lymphoma (Supplementary Table S1). However, the higher incidence of lymphoma in female $\mathrm{ku}^{-/-} \mathrm{bax} \mathrm{x}^{-/-}$mice may be reflective of the extended lifespan rather than an actual enhancement of tumorigenesis, as improved survival rate was more prominent in female than male $\mathrm{ku}_{70^{-1-}}$ bax ${ }^{-/-}$mice that showed no increased tumor incidence. These results further suggest that the partial suppression of Bax-mediated cell death, rather than complete suppression, may be more beneficial for the lifespan extension in Ku70-null mice without an increase in cancer risk.

Presently, it is unclear why Bax deficiency was able to enhance survival in Ku70-null mice more profoundly in females than males. Our results suggest that the effects caused by Bax activation in $k u 70^{-/}$mice seem to be more detrimental to females than males, based on the observation that survival is more significantly enhanced in females when Bax is deleted. The deletion of Bax has been shown to negatively impact males, causing testicular degeneration and infertility. ${ }^{51}$ Conversely, bax ${ }^{-1-}$ females maintain fertility longer in life because of increased oocyte survival, ${ }^{52}$ and this improvement in ovarian function may contribute to the better health span seen in Bax-deficient Ku70-null females to further enhance their survival. However, altered gonadal function does not fully explain the improved survival and extended lifespan observed in Ku70-null mice because Bax haploinsufficiency does not cause the same changes in gonadal function as the complete deletion of Bax, yet both gene mutations result in similar survival rates. $\mathrm{Bax}^{+/-}$mice have functional ovaries and testes, and their reproduction is normal. ${ }^{51}$ Consistently, we observed successful mating and viable offspring from male and female $\mathrm{ku}^{-/} \mathrm{O}^{-} \mathrm{bax}{ }^{+/-}$mice. Therefore, the influence of gonadal function is not the only reason how Bax deficiency can extend lifespan.

In comparison with bax haploinsufficiency $\left(\right.$ bax $\left.^{+/-}\right)$, the complete deletion of bax $\left(b x^{-1-}\right)$ might have a greater protective influence on lung alveolar cells to suppress cell death caused by the absence of Ku70, and this might be why the maximum lifespan of $k u 70^{-/}$bax ${ }^{-/}$mice (951 days) was longer than that of $k u 70^{-/-} b_{a x}^{+/-}$mice (803 days) (Figure 1). However, the median survival of $\mathrm{ku}^{-1} \mathrm{O}^{-1} \mathrm{bax}^{-/-}$mice (38 weeks) and $\mathrm{ku}^{-1} \mathrm{O}^{-1} \mathrm{bax}^{+/-}$mice (37.5 weeks) did not show significant differences (Figure 1). The complete bax deletion is likely to enhance the survival of other cell types, such as the endothelial cells in the alveolar blood vessels, and this abnormality may cause a higher incidence of pulmonary blood vessel occlusion that we observed in the $k u 70^{-1}$ bax ${ }^{-/-}$ mice despite the increase in overall lifespan. In addition, $\mathrm{bax}^{-/-}$mice, but not $\mathrm{bax}^{+/-}$mice, have abnormally large brains because of increased neuronal survival during brain development ${ }^{32}$ that may have a negative impact on survival later in life. Furthermore, testicular development is suppressed in $\mathrm{bax}^{-/-}$mice, but not in bax ${ }^{+/-}$mice, and this leads to the absence of androgen synthesis in the testes. ${ }^{51}$ It is possible that the some of the benefits generated by Bax deletion in a Ku70-null background may be canceled by other inherent problems caused by the absence of Bax. In order to further examine the effects of Bax deletion, we are planning to conditionally knockout Bax in specific cell types, such as alveolar epithelial or endothelial cells, in a Ku70-null line.

In support of this study in which we have demonstrated a significant role of a pro-apoptosis gene in the induction of premature death in mutant mice with defects in DNA DSB repair, another report has shown that the deletion of PUMA, a $\mathrm{BH} 3-$ only protein that activates Bax-mediated cell death, was able to prolong the survival of telomerase-defective mutant mice. ${ }^{53}$ Previous studies have shown that $k u 70^{-1-}, k u 80^{-1}$, and $k u 70^{-1-} \mathrm{ku} 80^{-/-}$mice exhibit similar abnormal aging phenotypes, including shortened lifespans. ${ }^{6}$ As Ku70 protein

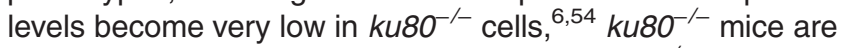
expected to be phenotypically similar to $k u 70^{-1-}$ mice and have an increased DNA damage response as well as a lower threshold to initiate Bax-mediated apoptosis. The deletion of p21 was unable to extend the survival of $\mathrm{ku}^{-1-} \mathrm{O}^{-1}$ mice, despite being able to suppress cellular senescence in $k u 80^{-/-}$MEFs. ${ }^{55}$ Importantly, this study shows that Bax deficiency can extend the 
survival and lifespan of $k u 70^{-/}$mice. Altogether, these observations suggest that apoptosis may potentially have a greater role than cellular senescence in lifespan determination, specifically in mice with defective NHEJ DNA repair.

This study also shows that Ku70 is essential to maintain normal lung alveolar structure and pulmonary arteries. Furthermore, this study suggests that Bax-mediated apoptosis plays a role in the development of emphysema in $k u 70^{-1-}$ mice. The hearts in aged $k u 70^{-/-}$mice (>7 months old) also had functional and structural defects, suggesting that Ku70 is required for the maintenance of heart function in older mice. It is not well understood how the DNA damage response promotes the development of emphysema, pulmonary artery occlusion, and heart failure; therefore, further studies are clearly needed to understand the role of Ku70 in the maintenance of homeostasis in the pulmonary and cardiovascular systems.

\begin{abstract}
Materials and Methods
Mouse husbandry and phenotypic observation. Genotyping for the Ku70 and Bax genes was performed as previously reported. ${ }^{2,51}$ First, $\mathrm{ku}^{\mathrm{N} \mathrm{O}^{+/-} \mathrm{bax}} \mathrm{x}^{+/-}$breeding pairs generated $\mathrm{ku}^{+0^{+/}} \mathrm{bax}^{+/+}, \mathrm{ku}^{-0^{-/}} \mathrm{bax}^{+/-}$, and $\mathrm{ku} \mathrm{O}^{-/-} \mathrm{bax}^{-/-}$mice in order to analyze their age-associated disease phenotypes and overall lifespans. The housing and phenotypic observation of these mice were performed as previously reported in articles analyzing the abnormal aging phenotype in $k u 70^{-1-}$ mice. ${ }^{6}$ All mice were observed at least 6 times a week for the entire course of their lifespans. Moribund mice showing weight loss and decreased responsiveness were continually monitored multiple times a day, and all the mice were killed when they became immobile and could no longer reach the water source. Morbidities were scored by Kaplan-Meier analysis and measured for statistical significance by the log-rank test. The killed mice were observed by necropsy, and organs were removed and fixed for histology. All mice were housed in microisolator cages in a specific pathogen-free environment. The rodent diet was irradiated, and the bedding, wire top, isolator cage, cardholders, water, and water bottles were autoclaved. All mouse procedures were done in accordance with the Guide for the Care and Use of Laboratory Animals and approved by the institutional IACUC.
\end{abstract}

Analysis of lung alveolar structure and size. Lungs were collected and fixed by intratracheal instillation of $4 \%$ paraformaldehyde to maintain the alveolar structure according to previously published methods. ${ }^{52}$ Tissue sections ( $7 \mu \mathrm{m}$ thick) of the upper left lobe were prepared for analysis. To determine the differences in alveolar size, measurements of mean linear intercept $\left(L_{m}\right)$ were used. $L_{m}$ was calculated as previously described. ${ }^{53,54}$ Pictures of at least 12 representative fields of lung sections were taken, avoiding large airways and blood vessels. Equidistant transverses of known length were superimposed on each picture and $L_{m}$ was determined with the equation: $L_{m}=(N)(L) / m$, where $N=$ number of transverses in the image, $L=$ length of each transverse, and $m=$ sum of all intercepts. $L_{m}$ was calculated for horizontal and vertical transverses, separately. For the horizontal transverses the values were $N=22, L=461.25 \mu \mathrm{m}$ and for the vertical transverses, $N=29, L=345.94 \mu \mathrm{m}$.

Immunohistochemistry. Harvested lungs were perfused, and hearts were incubated in a solution of $250 \mathrm{mM}$ potassium chloride before fixation. All tissues were fixed overnight in $4 \%$ neutral buffered paraformaldehyde and then stored in sterile PBS at $4^{\circ} \mathrm{C}$ before being processed, embedded in paraffin, and sectioned $(5-7 \mu \mathrm{m})$. Sections were deparaffinized in xylene, rehydrated in a graded ethanol series, and incubated in a solution of $3 \% \mathrm{H}_{2} \mathrm{O}_{2}$ in methanol for $20 \mathrm{~min}$ in order to quench endogenous peroxidase activity. Antigen retrieval was performed according to the manufacturer's instructions for the Biocare Medical Decloaking Chamber system (Concord, CA, USA). All sections were blocked for $1 \mathrm{~h}$ at room temperature before an overnight incubation in the primary antibody. The Vectastain Elite ABC Kit (Vector Laboratories, Burlingame, CA, USA; PK-6101) was used according to the manufacturer's instructions. Positive staining was visualized with DAB (ImmPACT DAB, Vector Laboratories, SK-4105). All sections were counterstained with hematoxylin for $30 \mathrm{~s}$ and dipped in acid alcohol as needed before being dehydrated and coverslipped. The following primary antibodies were used: phospho- $\gamma$-H2A.X (Cell Signaling Technologies, Danvers, MA, USA; no. 9718, $1: 300$ ), cleaved caspase-3 (Cell Signaling Technologies, Cambridge, MA, USA; no. 9664, 1:200), Ki67 (Abcam, Cambridge, MA, USA; ab15580, 1:200), $\alpha$-smooth muscle actin (Abcam; ab5694, 1 : 5000) vWF (Dako, Carpenteria, CA, USA; A0082, 1:5000), CD45 (BD Pharmingen, San Diego, CA, USA; no. 550539, 1:50), T1 $\alpha$ (lowa Hybridoma Bank, lowa City, IA, USA; clone 8.1.1, $5 \mu \mathrm{g} / \mathrm{ml}$ ), and pro-surfactant protein C (Millipore, Temecula, CA, USA; AB3786, $1: 4000$ ). Images were acquired using a Nikon Eclipse TE2000-S microscope (Melville, NY, USA) and the Metamorph software (Sunnyvale, CA, USA).

Generation and culture of MEFs. MEF cultures were prepared from 14- to 15-day-old embryos from intercrossed $k u 70^{+/-}$bax ${ }^{+/-}$mice. After each embryo was removed and washed in PBS, the dark-colored visceral tissue from the abdominal region was removed. The remaining tissue was minced and digested in $0.25 \%$ trypsin for $20 \mathrm{~min}$ at $37^{\circ} \mathrm{C}$ in $5 \% \mathrm{CO}_{2}$. The tissue was further broken down by pipetting before being plated onto a $10 \mathrm{~cm}^{2}$ dish in DMEM supplemented with $10 \%$ FBS, $1 \%$ non-essential amino acids, $1 \%(10 \mathrm{mM})$ L-glutamine, $1 \%(5 \mathrm{mM})$ sodium pyruvate, and $1 \%(50 \mathrm{U})$ of penicillin and streptomycin. At $80-90 \%$ confluency, the cells were passaged and plated in a 1:5 dilution. The cells were deemed MEFs once they acquired fibroblast cell morphology. The genotype of each embryo was confirmed with PCR as previously reported. ${ }^{2,51}$

Cell death assay. Wild-type and $k u 70^{-1}$ MEFs were plated onto a 6 -well plate at a density of 200000 cells per well and treated with $1.0 \mu \mathrm{M}$ Doxorubicin (SigmaAldrch, St. Louis, MO, USA; 44583) for $24 \mathrm{~h}$. Floating dead cells were collected, and the live cells were detached using $0.05 \%$ trypsin. After pelleting the cells and resuspending the cells to get a total volume of $100 \mu$, the live and dead cells were counted manually based on Trypan blue dye exclusion. Apoptosis in tissue sections was detected by TUNEL staining using the in situ Apoptosis Detection Kit (4810-30-K, TAVS2 TdT-DAB; Trevigen, Gaithersburg, MD, USA).

Cellular senescence assay. Wild-type and $k u 70^{-/-}$MEFs were plated onto a 24-well plate at a density of 10000 cells per well and cultured overnight. On the following day, cells were washed with warm $\left(37^{\circ} \mathrm{C}\right) \mathrm{HBSS}$ and then fixed with $4 \%$ neutral buffered paraformaldehyde for $10 \mathrm{~min}$ at room temperature. The senescence detection kit (Biovision, Milpitas, CA, USA; no. K320-250) was used according to the manufacturer's instructions to observe senescence-associated $\beta$-galactosidase activity in the MEFs.

Western blotting. At 80-90\% confluency, the floating dead cells were removed with HBSS. The remaining cells were scraped on ice, pelleted, and incubated in RIPA lysis buffer ( $150 \mathrm{mM} \mathrm{NaCl}, 1 \% \mathrm{NP}-40,0.5 \%$ sodium deoxycholate, and $0.1 \%$ SDS in PBS) containing a protease inhibitor cocktail (Thermo Scientific, Waltham, MA, USA; no. 87786) and PMSF for $20 \mathrm{~min}$ at $4^{\circ} \mathrm{C}$. The total cell lysate was cleared via centrifugation at a speed of 14000 r.p.m. (18 626 r.c.f.) for $30 \mathrm{~min}$ at $4^{\circ} \mathrm{C}$. After determining the protein concentration using a Bradford assay (Bio-Rad, Hercules, CA, USA; no. 500-0006), $5 \mu \mathrm{g}$ of protein was prepared in Laemmli sample buffer, heat inactivated at $95^{\circ} \mathrm{C}$ for $5 \mathrm{~min}$, separated using a 4-12\% SDS-polyacrylamide gel (Life Technologies, Carlsbad, CA, USA, NuPAGE), and then transferred overnight onto a nitrocellulose membrane. The membranes were then dried at $65^{\circ} \mathrm{C}$ for $20 \mathrm{~min}$ before being blocked for $1 \mathrm{~h}$ at room temperature in $5 \% \mathrm{BSA}, 3 \%$ milk, and $2 \%$ normal serum of the host species from which the secondary antibody was derived. The following primary antibodies were used: Ku70 N3H10 (NeoMarkers, Fremont, CA, USA; 1: 500), Bax N20 (Santa Cruz Biotechnology, Inc., Dallas, TX, USA; sc-493, $1: 1000$ ), Caspase 3 (Cell Signaling; $1: 1000$ ), and $\beta$-actin (SigmaAldrich, A5441, 1:40000). Horseradish peroxidase-conjugated goat anti-mouse (Life Technologies) or anti-rabbit lgG (Dako) was used as the secondary antibody. The incubation time for each primary antibody was $1 \mathrm{~h}$ at room temperature or overnight at $4{ }^{\circ} \mathrm{C}$, and the secondary antibodies were incubated for $1 \mathrm{~h}$ at room temperature. The bands were visualized using an ECL detection system (GE Healthcare, Pittsburgh, PA, USA; RPN2132).

Echocardiography. Echocardiography was performed as previously described. ${ }^{45}$ Briefly, animals were anesthetized with $2 \%$ isoflurane supplemented with $\mathrm{O}_{2}$ in an isoflurane induction chamber and maintained with $1.5 \%$ isoflurane by nose cone. After depilating the chest, the extremities were secured to a warming pad (Braintree Scientific, Braintree, MA, USA) with paper tape, and needle electrodes were connected to a preamplifier to simultaneously record a single lead electrocardiogram. All image acquisitions and offline measurements were 
conducted by a single investigator who was blinded to animal groups. Image processing and data analysis were performed on the ultrasonograph using Syngo Vector Imaging technology software (Siemens Medical Solutions, Malvern, PA, USA).

Statistical analyses. Statistical analyses were performed using GraphPad Prism for Windows, version 6.0 (GraphPad Software, San Diego, CA, USA). The log-rank test was used to compare the survival curves, and Student's $t$-test was used to compare the genotypes where appropriate.

\section{Conflict of Interest}

The authors declare no conflict of interest.

Acknowledgements. We greatly appreciate the advice given by Dr. Mukesh Jain and Dr. Christopher G Wilson who are experts in heart and lung pathology, respectively. This work was supported in part by the National Institutes of Health (NIH) Grant R01AG031903 (to SM). The study was also supported in part by the Flow Cytometry and Confocal Microscopy core facilities in the Comprehensive Cancer Center of Case Western Reserve University and University Hospital P30CA43703.

1. Downs JA, Jackson SP. A means to a DNA end: the many roles of Ku. Nat Rev Mol Cell Biol 2004; 5: 367-378

2. Gu Y, Jin S, Gao Y, Weaver DT, Alt FW. Ku70-deficient embryonic stem cells have increased ionizing radiosensitivity, defective DNA end-binding activity, and inability to support V(D)J recombination. Proc Natl Acad Sci USA 1997; 94: 8076-8081.

3. Gu Y, Seidl KJ, Rathbun GA, Zhu C, Manis JP, van der Stoep N et al. Growth retardation and leaky SCID phenotype of Ku70-deficient mice. Immunity 1997; 7: 653-665.

4. Li GC, Ouyang H, Li X, Nagasawa H, Little JB, Chen DJ et al. Ku70: a candidate tumor suppressor gene for murine T cell lymphoma. Mol Cell 1998; 2: 1-8.

5. Manis JP, Gu Y, Lansford R, Sonoda E, Ferrini R, Davidson L et al. Ku70 is required for late B cell development and immunoglobulin heavy chain class switching. J Exp Med 1998; 187 2081-2089.

6. Li H, Vogel H, Holcomb VB, Gu Y, Hasty P. Deletion of Ku70, Ku80, or both causes early aging without substantially increased cancer. Mol Cell Biol 2007; 27: 8205-8214.

7. Gu Y, Sekiguchi J, Gao Y, Dikkes P, Frank K, Ferguson D et al. Defective embryonic neurogenesis in Ku-deficient but not DNA-dependent protein kinase catalytic subunitdeficient mice. Proc Natl Acad Sci USA 2000; 97: 2668-2673.

8. Gomez JA, Gama V, Yoshida T, Sun W, Hayes P, Leskov K et al. Bax-inhibiting peptides derived from Ku70 and cell-penetrating pentapeptides. Biochem Soc Trans 2007; 35(Pt 4): 797-801.

9. Gross A, McDonnell JM, Korsmeyer SJ. BCL-2 family members and the mitochondria in apoptosis. Genes Dev 1999; 13: 1899-1911.

10. Wei MC, Zong WX, Cheng EH, Lindsten T, Panoutsakopoulou V, Ross AJ et al. Proapoptotic BAX and BAK: a requisite gateway to mitochondrial dysfunction and death. Science 2001 292: 727-730.

11. Kim SH, Kim D, Han JS, Jeong CS, Chung BS, Kang CD et al. Ku autoantigen affects the susceptibility to anticancer drugs. Cancer Res 1999; 59: 4012-4017.

12. Gama V, Gomez JA, Mayo LD, Jackson MW, Danielpour D, Song K et al. Hdm2 is a ubiquitin ligase of Ku70-Akt promotes cell survival by inhibiting Hdm2-dependent Ku70 destabilization. Cell Death Differ 2009; 16: 758-769.

13. Cohen HY, Lavu S, Bitterman KJ, Hekking B, Imahiyerobo TA, Miller $C$ et al. Acetylation of the $\mathrm{C}$ terminus of Ku70 by CBP and PCAF controls Bax-mediated apoptosis. Mol Cell 2004 13: $627-638$

14. Cohen HY, Miller C, Bitterman KJ, Wall NR, Hekking B, Kessler B et al. Calorie restriction promotes mammalian cell survival by inducing the SIRT1 deacetylase. Science 2004; 305 : 390-392.

15. Subramanian C, Opipari AW Jr., Bian X, Castle VP, Kwok RP. Ku70 acetylation mediates neuroblastoma cell death induced by histone deacetylase inhibitors. Proc Natl Acad Sci USA 2005; 102: 4842-4847.

16. Li Y, Yokota T, Gama V, Yoshida T, Gomez JA, Ishikawa K et al. Bax-inhibiting peptide protects cells from polyglutamine toxicity caused by Ku70 acetylation. Cell Death Differ 2007; 14: 2058-2067.

17. Mazumder S, Plesca D, Kinter M, Almasan A. Interaction of a cyclin E fragment with ku70 regulates bax-mediated apoptosis. Mol Cell Biol 2007; 27: 3511-3520.

18. Plesca D, Mazumder S, Gama V, Matsuyama S, Almasan A. A C-terminal fragment of cyclin $\mathrm{E}$, generated by caspase-mediated cleavage, is degraded in the absence of a recognizable phosphodegron. J Biol Chem 2008; 283: 30796-30803.

19. lijima K, Muranaka C, Kobayashi J, Sakamoto S, Komatsu K, Matsuura S et al. NBS1 regulates a novel apoptotic pathway through Bax activation. DNA Repair (Amst) 2008; 7 1705-1716.
20. Anekonda TS, Adamus G. Resveratrol prevents antibody-induced apoptotic death of retinal cells through upregulation of Sirt1 and Ku70. BMC Res Notes 2008; 1: 122.

21. Pucci S, Mazzarelli P, Sesti F, Boothman DA, Spagnoli LG. Interleukin-6 affects cell death escaping mechanisms acting on Bax-Ku70-Clusterin interactions in human colon cancer progression. Cell Cycle 2009; 8: 473-481.

22. Sundaresan NR, Samant SA, Pillai VB, Rajamohan SB, Gupta MP. SIRT3 is a stressresponsive deacetylase in cardiomyocytes that protects cells from stress-mediated cell death by deacetylation of Ku70. Mol Cell Biol 2008; 28: 6384-6401.

23. Trougakos IP, Lourda M, Antonelou MH, Kletsas D, Gorgoulis VG, Papassideri IS et al. Intracellular clusterin inhibits mitochondrial apoptosis by suppressing p53-activating stress signals and stabilizing the cytosolic Ku70-Bax protein complex. Clin Cancer Res 2009; 15: 48-59.

24. Yamaguchi $\mathrm{H}$, Woods NT, Piluso LG, Lee HH, Chen J, Bhalla KN et al. p53 acetylation is crucial for its transcription-independent proapoptotic functions. J Biol Chem 2009; 284: 11171-11183.

25. Vishnudas VK, Miller JB. Ku70 regulates Bax-mediated pathogenesis in laminin-alpha2deficient human muscle cells and mouse models of congenital muscular dystrophy. Hum $\mathrm{Mol}$ Genet 2009; 18: 4467-4477.

26. Zou H, Volonte D, Galbiati F. Interaction of caveolin-1 with Ku70 inhibits Bax-mediated apoptosis. PLoS One 2012; 7: e39379.

27. Dumitru R, Gama V, Fagan BM, Bower JJ, Swahari V, Pevny LH et al. Human embryonic stem cells have constitutively active Bax at the Golgi and are primed to undergo rapid apoptosis. Mol Cell 2012; 46: 573-583

28. Li JJ, Gu QH, Li M, Yang HP, Cao LM, Hu CP. Role of Ku70 and Bax in epigallocatechin-3gallate-induced apoptosis of A549 cells in vivo. Oncol Lett 2013; 5: 101-106.

29. Wang B, Xie M, Li R, Owonikoko TK, Ramalingam SS, Khuri FR et al. Role of Ku70 in deubiquitination of Mcl-1 and suppression of apoptosis. Cell Death Differ 2014; 21 : $1160-1169$.

30. De Zio D, Bordi M, Tino E, Lanzuolo C, Ferraro E, Mora E et al. The DNA repair complex Ku70/86 modulates Apaf1 expression upon DNA damage. Cell Death Differ 2011; 18: 516-527.

31. Harper JM, Wilkinson JE, Miller RA. Macrophage migration inhibitory factor-knockout mice are long lived and respond to caloric restriction. FASEB J 2010; 24: 2436-2442.

32. White FA, Keller-Peck CR, Knudson CM, Korsmeyer SJ, Snider WD. Widespread elimination of naturally occurring neuronal death in Bax-deficient mice. J Neurosci 1998; 18: 1428-1439.

33. Gama V, Yoshida T, Gomez JA, Basile DP, Mayo LD, Haas AL et al. Involvement of the ubiquitin pathway in decreasing Ku70 levels in response to drug-induced apoptosis. Exp Cell Res 2006; 312: 488-499.

34. Azam S, Desjardins CL, Schluchter M, Liner A, Stelzer JE, Yu X et al. Comparison of velocity vector imaging echocardiography with magnetic resonance imaging in mouse models of cardiomyopathy. Circ Cardiovasc Imaging 2012; 5: 776-781.

35. Vogel H, Lim DS, Karsenty G, Finegold M, Hasty P. Deletion of Ku86 causes early onset of senescence in mice. Proc Natl Acad Sci USA 1999; 96: 10770-10775.

36. Mounkes LC, Stewart CL. Aging and nuclear organization: lamins and progeria. Curr Opin Cell Biol 2004; 16: 322-327.

37. Mounkes LC, Kozlov S, Hernandez L, Sullivan T, Stewart CL. A progeroid syndrome in mice is caused by defects in A-type lamins. Nature 2003; 423: 298-301.

38. Thurlbeck WM, Muller NL. Emphysema: definition, imaging, and quantification. AJR Am J Roentgenol 1994; 163: 1017-1025.

39. Turato G, Zuin R, Saetta M. Pathogenesis and pathology of COPD. Respiration 2001; 68: 117-128.

40. Koike M, Yutoku Y, Koike A. The defect of Ku70 affects sensitivity to X-ray and radiation-induced caspase-dependent apoptosis in lung cells. J Vet Med Sci 2012; 75: 415-420.

41. Koike M, Yutoku Y, Koike A. Accumulation of Ku70 at DNA double-strand breaks in living epithelial cells. Exp Cell Res 2011; 317: 2429-2437.

42. Nicolls MR, Mizuno S, Taraseviciene-Stewart L, Farkas L, Drake Jl, Al Husseini A et al. New models of pulmonary hypertension based on VEGF receptor blockade-induced endothelial cell apoptosis. Pulm Circ 2012: 2: 434-442.

43. Voelkel NF, Gomez-Arroyo J, Abbate A, Bogaard HJ, Nicolls MR. Pathobiology of pulmonary arterial hypertension and right ventricular failure. Eur Respir J 2012; 40: 1555-1565.

44. Bourke SJ. Interstitial lung disease: progress and problems. Postgrad Med J 2006; 82 : 494-499.

45. Morgan EE, Faulx MD, McElfresh TA, Kung TA, Zawaneh MS, Stanley WC et al. Validation of echocardiographic methods for assessing left ventricular dysfunction in rats with myocardial infarction. Am J Physiol Heart Circ Physiol 2004; 287: H2049-H2053.

46. Miyashita T, Reed JC. Tumor suppressor p53 is a direct transcriptional activator of the human bax gene. Cell 1995; 80: 293-299.

47. Holcomb VB, Vogel H, Marple T, Kornegay RW, Hasty P. Ku80 and p53 suppress medulloblastoma that arise independent of Rag-1-induced DSBs. Oncogene 2006; 25 . 7159-7165.

48. Li H, Choi YJ, Hanes MA, Marple T, Vogel H, Hasty P. Deleting Ku70 is milder than deleting Ku80 in p53-mutant mice and cells. Oncogene 2009; 28: 1875-1878.

49. Van Nguyen T, Puebla-Osorio N, Pang H, Dujka ME, Zhu C. DNA damage-induced cellular senescence is sufficient to suppress tumorigenesis: a mouse model. J Exp Med 2007; 204: 1453-1461. 
50. Foster SS, De S, Johnson LK, Petrini JH, Stracker TH. Cell cycle- and DNA repair pathwayspecific effects of apoptosis on tumor suppression. Proc Natl Acad Sci USA 2012; 109: 9953-9958.

51. Knudson CM, Tung KS, Tourtellotte WG, Brown GA, Korsmeyer SJ. Bax-deficient mice with lymphoid hyperplasia and male germ cell death. Science 1995; 270: 96-99.

52. Perez Gl, Jurisicova A, Wise L, Lipina T, Kanisek M, Bechard A et al. Absence of the proapoptotic Bax protein extends fertility and alleviates age-related health complications in female mice. Proc Natl Acad Sci USA 2007; 104: 5229-5234.

53. Sperka T, Song Z, Morita Y, Nalapareddy K, Guachalla LM, Lechel A et al. Puma and p21 represent cooperating checkpoints limiting self-renewal and chromosomal instability of somatic stem cells in response to telomere dysfunction. Nat Cell Biol 2012; 14: 73-79.

54. Koike M, Koike A. The Ku70-binding site of Ku80 is required for the stabilization of Ku70 in the cytoplasm, for the nuclear translocation of Ku80, and for Ku80-dependent DNA repair. Exp Cell Res 2005; 305: 266-276.
55. Zhao B, Benson EK, Qiao R, Wang X, Kim S, Manfredi JJ et al. Cellular senescence and organismal ageing in the absence of $\mathrm{p} 21(\mathrm{CIP} 1 / \mathrm{WAF} 1)$ in ku80 $(-/-)$ mice. EMBO Rep 2009; 10: 71-78.

(c) (i) Cell Death and Disease is an open-access journal published by Nature Publishing Group. This work is licensed under a Creative Commons Attribution 4.0 International Licence. The images or other third party material in this article are included in the article's Creative Commons licence, unless indicated otherwise in the credit line; if the material is not included under the Creative Commons licence, users will need to obtain permission from the licence holder to reproduce the material. To view a copy of this licence, visit http://creativecommons.org/licenses/by/4.0

Supplementary Information accompanies this paper on Cell Death and Disease website (http://www.nature.com/cddis) 